\title{
Metal Concentration in Three Popular Local Drinks Consumed in Benue State, Nigeria
}

\author{
Kemasuode, T $^{1}$, Okoye, B. C. O. ${ }^{2}$, Gav, B. L. ${ }^{3}$ \\ ${ }^{1,2}$ Department of Chemistry, University of Nigeria Nusukka, Nigeria \\ ${ }^{2}$ Department of Chemistry, Federal university of Agriculture ,P.M.B.2373 Makurdi, Nigeria
}

\begin{abstract}
The study was carried out on assessment of metal concentration in three popular local drinks consumed in Benue State, Nigeria. Burukutu, Kunu and Zobo samples were collected in five local Governments and were analyzed for trace metals(Cu, Zn, Fe, $\mathrm{Mn}, \mathrm{Pb}, \mathrm{Cr}$ and $\mathrm{Ni}$ (except $\mathrm{Na}, \mathrm{K}, \mathrm{Ca}$ and $\mathrm{Mg}$ ) using atomic absorption spectrophotometer. $\mathrm{Na}$ and $\mathrm{K}$ were analyzed using Flame Photometer while Mg and Ca were determined using EDTA titration. The results obtained from the local drink samples in mg/L showed that $\mathrm{Cu}$ ranged from below detectable level to 0.01; $\mathrm{Zn}(0.47$ to 0.5$) ; \mathrm{Fe}(0.1$ to 1.40$) ; \mathrm{Mn}(0.05$ to 0.16$) ; \mathrm{Pb}(0.03$ to 0.08$) ; \mathrm{Cr}(0.02$ to 0.05$)$; $\mathrm{Ni}($ below detectable level to 0.01); $\mathrm{Ca}(25.28$ to 36.64); $\mathrm{Mg}(4.77$ to 4.95); $\mathrm{Na}(3.66$ to 4.74) and $\mathrm{K}(5.26$ to 7.66$)$. The results showed that the concentration range for $P b(0.030 .08 \mathrm{mg} / \mathrm{L})$ were above the $W H O$ recommended guideline of $0.01 \mathrm{mg} / \mathrm{L}$ for beverages drinks. The average concentration value for Fe in Burukutu drink $(1.40 \mathrm{mg} / \mathrm{L})$ and $\mathrm{Kunu}(0.98 \mathrm{mg} / \mathrm{L})$ were higher than the WHO recommended guidelines of $0.3 \mathrm{mg} / \mathrm{L}$ for beverage drinks, while the Fe concentration for Zobo samples $(0.18 \mathrm{mg} / \mathrm{L})$ falls below the WHO permissible limit of $0.3 \mathrm{mg} / \mathrm{L}$ for beverage drinks. The concentration levels of other metals were either below detectable level or falls within the WHO standard guideline for beverage drinks. However, the presence of some heavy metals especially lead and iron in these local drinks were localized pollutional influences, which is a pointer to the contamination source as few of the samples that were affected. The reason for higher lead levels was as a result of the source of water and iron levels in Burukutu and Kanu drinks was attributed to use of rusting metal drums and vessels used in processing of the two drinks, unlike Zobo drink which does not require the same processing of method. Therefore, consumers should be careful of the environment where those drinks are prepared, as well as the vessels used.
\end{abstract}

Keyword: Trace metals , Burukutu, Kunu, Zobo, AAS

\section{Introduction}

The knowledge of metals in foods is essential for calculating the dietary intakes of essential metals and evaluation of human exposure to toxic elements [I]. Apart from fruits juices and concentrates, other plant materials are often used in the preparation of alcoholic and non-alcoholic beverages. The simplicity of production availability of raw materials in many rural communities has resulted to an increase in production and consumption of many local beverages at cottage levels in Nigeria. The local beverages are also reported to have various medicinal values.

Determination of trace metals is of interest because while some are essential nutrient some are toxic. Metals like Zinc, Manganese, Copper, Chromium, Iron, and Cobalt are essential trace elements for humans, animals and plants. Heavy metals such as Lead, Cadmium, Nickel, Arsenic, and Mercury are toxic even at low level, found to have harmful effect on human physiology and other biological systems when they are above the tolerance level. Excessive intake of these toxic heavy metals can lead to several diseases such as organ failure, cancers, retardation of mental development in children in pregnant women [2]. It is important to monitor the level of such pollutants in the environments especially the foods and drinks consumed in the rural areas of developing countries like Nigeria which suffers neglect from the government.

Burukutu, a popular alcoholic drink among indigenes of the middle belt region of Nigeria, is a local brew made from fermented sorghum and other protein enriched grains. The age long drink, also known as BKT, serves as a source of alcohol for those who lack the financial means to patronize refined brew like beer and other foreign or imported drinks In Benue State, almost every community have a designated joint dedicated to the sale and drinking of Burukutu, the joint opens as early as 6.am and lasts till midnights with mostly men and women engaged in different kind of games as the drinks by flow amidst entertainment provided by local musicians and dancers. The joints also serve as pool for men willing to donate blood on demands due to the nutritional value of the drink. Inspite of the sanitary condition in the various Bukurutu joints, relations of sick people patronize them to solicit for willing to donate blood for a fee[3].

Kunu is a popular drink consumed throughout Nigeria, mostly in the North. It is usually made from grains such as millet or sorghum, although it can be made from maize as well. The variety of the drink made from sorghum is a milky light -brown colour, while Kunu made from millet and maize is whitish in colour[4].

Zobo is a healthy Nigeria drink from the dried red calyces and sepals of the Roselle plant (Hibiscus Sabdariffa) known as Zobo leaves in Nigeria. Zobo is usually served as a chilled refreshing drink but can also be enjoyed as a relaxing hot tea and leaves used in production of jam/jelly, food colouring, syrups and soup/sauces. According to several scientific investigations, weather in form of tea,jams or sauces is said to help reduce high blood pressure, aid digestion, promote the health of the urinary tract and also great for overall health.

According to several scientific investigations, millet and other grains use in the production of these local drinks contains a poly-nutrient called ligman, which has cancer fighting properties and is beneficial in the treatment of heart 


\section{International Journal of Science and Research (IJSR) \\ ISSN (Online): 2319-7064 \\ Index Copernicus Value (2013): 6.14 | Impact Factor (2014): 5.611}

disease. It is also known to reduce the risks associated with diabetes. Burukutu, Kunu and Zobo are good for woman that have reached the stages of menopause as to helps them relax their muscles. These drinks are recommended for nursing mothers as they help increase the flow of their milk. These drinks contain fibre thus helping to promote a healthy digestive system and also help in the prevention of chronic inflammatory diseases such as rheumatoid arthritis. Water is the main component of these drinks, the concentrations of metals of these popular local drinks may be related to the purity of the water used in the production processes. The processing of these local drinks is carried out in a small scale enterprise involving the possible use of low water quality, there is a distinct possibility of contamination of these products with understand able elements[5]. The availability of metals in our local drinks may be as result of the bioaccumulated metals in the plants which are used for the production processes.

\section{Materials and Methods}

Study area: Benue State is one of 36 states in the Federal Republic of Nigeria. It is located North-Central of Nigeria. The state is made of twenty three Local Government Areas. Benue State lies within the lower river Benue trough in the middle belt region of Nigeria. Its geographic coordinates are longitude $7^{\circ} 47^{\prime}$ and $100^{\prime}$ East. Latitude $6^{\circ} 25^{\prime}$ and $8^{\circ} 8^{\prime}$ North and shares boundaries with five other States namely: Nasarawa State to the North, Taraba State to the east, CrossRiver State to the south, Enugu State to the south-west and Kogi State to the west. The state also shares a common boundary with the Republic of Cameroon on the south-east. Benue occupies a landmass of 34,059 square kilometers(Fig1). According to 2006 census, the state has a population of about $4,253,641$. It is inhabited predominately by Tiv and Idoma peoples, who speak the Tiv language and Idoma language respectively. There are other ethnic groups, including the Igede ,Etulo and Abakwa, Jukun, Hausa, Akweya and Nyifon. With its capital at Makurdi, Benue is a rich agricultural region; some of the crops grown there are potatoes, cassava, soyabean, guinea corn, sorghum, flax, yams, sesame, rice and grand nuts[6].

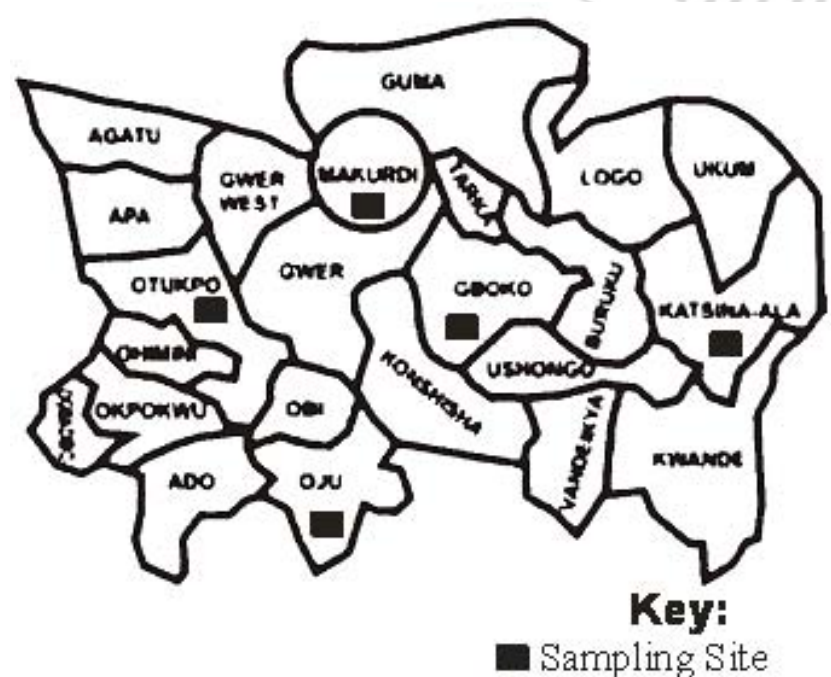

Figure 1: Map of Benue State showing the sampling site
The physical features of the area are generally low lying (averaging $100 \mathrm{~m}-250 \mathrm{~m}$ ) and gently undulating with occasional inselbergs,knoll,laterite etc. It has a typical climate of the tropical zone because of its location. Its climate is quite pleasant with an average maximum and minimum temperatures of $35^{\circ} \mathrm{c}$ and $21^{\circ} \mathrm{c}$ in summer and 37 ${ }^{\circ} \mathrm{c}$ and $16{ }^{\circ} \mathrm{c}$ in winter respectively. The climate is characterized by two distinct seasons, wet and dry. The dry season spans from October to March while the wet season is from April to September. The month of December, January and February are cold due to harmattern wind blowing across the Local Government areas from the North-East of Nigeria. The sediments are generally sandy-loam shelf basement complex and alluvial plain. The vegetation of the state consists of rain forests which have tall trees, tall grasses and oil palm trees. More than 80 percent of the inhabitants are predominately farmers [6].

\section{Sample Collection}

A total of fifteen freshly prepared samples of Burukutu, Kunu, and Zobo drinks were randomly bought from five different producers each in Makurdi, Gboko, Otukpo, Oju and Katsina-Ala towns of Benue State, Nigeria. All the samples were collected in a clean plastic bottles on the $16^{\text {th }}$ and $17^{\text {th }}$ October,2015 and were kept in deep freezer prior to analysis.

\section{Sample treatment}

Prior to analysis, the samples were degassed using ultrasonic bath for 5 minutes and the samples were digested according to the Aqua Regia method. In this method $30 \mathrm{~cm}^{3}$ of Aqua solution (mixture of $\mathrm{HNO}_{3}$ and $\mathrm{HCl}$ in the ratio 3:1) was added to $3 \mathrm{~cm}^{3}$ of the sampes and the mixture was heated on a hot plate in a fume cupboard until complete clarification were observed. The samples were allowed to cool at room temperature, filtered and made up to $100 \mathrm{~cm}^{3}$ with deionized water which were forwarded for metal analysis.

\section{Mineral Analysis}

All the digested samples were subjected to elemental analysis (except $\mathrm{Na}, \mathrm{K}, \mathrm{Ca}$, and $\mathrm{Mg}$ ) using Atomic Absorption spectrophotomer(AAS) for trace metals in triplicate. Sodium and Potassium were analyzed using flame phometer while $\mathrm{Ca}$ and $\mathrm{Mg}$ were analyzed using EDTA titration. The instrument setting and operational conditions were done in accordance with the manufacture's specification.

\section{Statistical Analysis}

All the data generated were analyzed statistically [7] Parameters evaluated were means, standard deviation and coefficient of variation percentage. All the data were determined in triplicate.

\section{Results and Discussion}

The result of trace metals in Burukutu alcoholic drinks consumed in Makurdi, Gboko, Otukpo, Oju and katsina-Ala towns of Benue State is shown in Table 1. Copper was not at detectable range in all the five towns where these samples were collected. Also Lead was not detected in Makurdi,Gboko, Otukpo and Katsina - Ala samples of Burukutu collected in these towns while Chromium was not 


\section{International Journal of Science and Research (IJSR) \\ ISSN (Online): 2319-7064 \\ Index Copernicus Value (2013): 6.14 | Impact Factor (2014): 5.611}

detected in Burukutu samples collected in Makurdi , Gboko, Otukpo and Oju towns. Nickel was not at detectable range inBurukutu samples of Makudi, Gboko, Oju and Katsina Ala towns. Among the detectable trace metals in Burukutu samples collected, Calcium had the highest metal concentration in Burukutu samples collected followed magnesium. The concentration of Calcium in Makurdi Burukutu sample was $37.27 \mathrm{mgL}^{-1}$, Gboko Burukutu sample was $21.71 \mathrm{mgL}^{-1}$, Otukpo Burukutu $19.43 \mathrm{mgL}^{-1}$, Oju Burukutu $26.45 \mathrm{mgL}^{-1}$ and Katsina -Ala $21.53 \mathrm{mgL}^{-1}$ followed by Magnesium with metal concentration of Burukutu in Makurdi $5.42 \mathrm{mgL}^{-1}$, Gboko $5.49 \mathrm{mgL}^{-1}$, Otukpo $4.11 \mathrm{mgL}^{-1}$, Oju $4.51 \mathrm{mgL}^{-1}$ and Katsina -Ala 521 $\mathrm{mgL}^{-1}$. The least concentrated trace metal was Nickel for all the Burukutu samples collected in the five areas of the State. The highest variability was found in Lead and Chromium $(170 \%$ ) while Magneium was the least varied $(10.91 \%)$. The order of abundance was found to be as: $\mathrm{Ca}>\mathrm{K}>\mathrm{Mg}>\mathrm{Na}>\mathrm{Fe}>\mathrm{Zn}>\mathrm{Mn}>\mathrm{Pb}>\mathrm{Cr}>\mathrm{Ni}$.

The level of trace metals in Kunu drinks comsumed in Makurdi, Gboko, Otukpo, Oju and Katsina-Ala towns of Benue State is shown in table 2. Copper and Nickel were not at detectable range of Atomic Absorption Spectrophometer in all the five towns where Kunu samples were collected. Lead was not detected in Kunu samples of Gboko and Katsina-Ala town. Also Nickel was not at detectable range for samples collected Makurdi, Oju, Otukpo and KatsinaAla towns. Among the detectable trace metals in Kunu samples collected, Calcium had the highest metal concentration in Makurdi sample was $34.29 \mathrm{mgL}^{-1}, 35.12$ $\mathrm{mgL}^{-1}$ in Gboko sample, $27.56 \mathrm{mgL}^{-1}$ in Otukpo sample, $36.57 \mathrm{mgL}^{-1}$ in Oju sample and $36.52 \mathrm{mgL}^{-1}$ in Katsina- Ala sample, followed by magnesium with metal concentration of $4.11 \mathrm{mgL}^{-1}$ in Makurdi, $4.80 \mathrm{mgL}^{-1}$ in Gboko, $5.47 \mathrm{mgL}^{-1}$ in Otukpo, $4.11 \mathrm{mgL}^{-1}$ in Oju and $5.36 \mathrm{mgL}^{-1}$ in Katsina-Ala towns. The least concentrated trace metal was manganese for all the Kunu samples collected in the five sampling sites of the State. The highest variability was found in Chromium $(170 \%)$ and the least varied was Calcium $(9.82 \%)$. The order of abundance was found to be as: $\mathrm{Ca}>\mathrm{K}>\mathrm{Mg}>\mathrm{Na}>\mathrm{Fe}>\mathrm{Zn}>\mathrm{Mn}>\mathrm{Pb}>\mathrm{Cr}>\mathrm{Ni}$.

The levels of trace metals in Zobo drinks collected in Makurdi, Gboko, Otukpo, Oju and Katsina-Ala towns of Benue State is shown in Table 3. Copper was not at detectable range of AAS in Zobo drinks collected in Makurdi, Gboko, Otukpo, Oju and Katsina-Ala respectively. Manganese was not detected in Makurdi sample of Zobo drinks. Lead was not at detectable range in Zobo samples collected in Makurdi, Gboko, Otukpo, Oju and Katsina-Ala towns of the State. Chromium was also not at detectable range in Otukpo, Oju and Katsina-Ala towns respectively. Also Nickel was not detected in Makurdi, Gboko and Otukpo towns. Among the detectable trace metals in the Zobo samples, Calcium had the highest concentration followed by Magnesium. The concentration of Calcium in Makurdi Zobo drinks was $29.25 \mathrm{mg} \mathrm{L}^{-1}$, Oju $39.50 \mathrm{mgL}^{-1}$, and Katsina-Ala $40.00 \mathrm{mgL}^{-1}$, followed by magnesium with metal concentration of zobo in Makurdi, Gboko, Otukpo, and katsina-Ala was $4.36 \mathrm{mgL}^{-1}, 5.11 \mathrm{mgL}^{-1} 4.61 \mathrm{mgL}^{-1}$ and $5.42 \mathrm{mgL}^{-1}$ respectively. The least concentrated trace metal was Chromium (0.08 mgL-1) for the Zobo samples collected in the five sampling sites of the State. The highest variability was found in $\operatorname{Lead}(170 \%)$ while the least was manganese $(7.61 \%)$. The order of abundance was as follow: $\mathrm{Ca}>\mathrm{K}>\mathrm{Mg}>\mathrm{Na}>\mathrm{Fe}>\mathrm{Zn}>\mathrm{Mn}>\mathrm{Pb}>\mathrm{Cr}>\mathrm{Ni}$.

Comparison of the average levels of trace metals in Burukutu, Kunu and Zobo collected in the sampling sites of the state is displayed in Tab 4. Calcium has the highest concentration in all the popular local drinks ranging from $25.28 \mathrm{mgL}^{-1}$ in Burukutu, $34.01 \mathrm{mgL}^{-1}$ in Kunu and $36.64 \mathrm{mgL}^{-1}$ in Zobo followed by Magnesium ranging from $4.95 \mathrm{mgL}^{-1}, 4.77 \mathrm{mgL}^{-1}$ and $4.86 \mathrm{mgL}^{-1}$ in Buruku , Kunu and Zobo drinks respectively. It is a well known fact that mineral elements are necessary for life [8]. Calcium leads to be a kind of coordination among inorganic element, if excessive amount of potassium, Magnesium or Sodium are present in the body. Calcium is capable of assuming a corrective role [9]. Calcium plays an important role in blood clothing, in muscles contraction and in certain enzymes in metabolic processes. Magnesium functions as an essential constituent for bone structure of reproduction and for normal functioning of the nervous system. It is also a part of the enzymes system [10]. The Calcium and Magnesium content of the local drinks fall within the WHO recommended range and could be said to be desirable for drinking without adverse effect. Potassium concentrated values ranged from $5.26 \mathrm{mgL}^{-1}$ in Burukutu , $6.82 \mathrm{mgL}^{-1}$ in Kunu and $66 \mathrm{mgL}^{-1}$ in Zobo drinks . While the Sodium varied from $4.46 \mathrm{mgL}^{-1}$, $3.66 \mathrm{mgL}^{-1}$ and $4.74 \mathrm{mgL}^{-1}$ in Burukutu, Kunu and Zobo respectively. Potassium is primarily an intracellular cation found mostly bound to protein in the body along with Sodium where they influence osmotic pressure and contribute to normal $\mathrm{pH}$ equilibrium [9]. The sodium content in water is important for health reasons, except when combined with excessively high concentrations of sulphate such combination can lead to gastro-intestinal initiation for persons placed on low sodium diet as a result of heart, kidney or circulatory ailment or complications pregnancy. The usual $\mathrm{Na}$ diet allowed in local drinks is $20 \mathrm{mgL}^{-1}$ [11]. The values recorded for both $\mathrm{K}$ and $\mathrm{Na}$ in the present study fall within the WHO limits. The average concentration of Nickel was $0.01 \mathrm{mg} \mathrm{L}^{-1}$ in all the three local drinks in the sampling sites of the State. These values fall within the WHO limit. From these results prolonged intake of these drinks can cause decreased body weight, heart and liver damage and skin irritation. Even though a small amounts of Nickel are needed by human body to produce red blood cells[12].

The average concentration of Chromium was below the WHO standard of $0.05 \mathrm{mgL}^{-1}$ in the local beverage drinks under study. Chromium toxicity is very dependent on the species and oxidation states present. It is normally found in the considerably less toxic trivalent state in foods and is poorly absorbed in the gastrointestinal tract. Chromium has been reported to have beneficial effects on type 11 diabetes [2]. However, the hexavalent form is carcinogenic. It has been estimated that human requires nearly $1 \mathrm{ugcr} / \mathrm{day}$.

The average concentration of Lead in this study was above the WHO recommended standard of $0.01 \mathrm{mgL}^{-1}$ in the three local beverage drinks. The high content of Lead in the three samples could be the water source or the production 


\section{International Journal of Science and Research (IJSR) \\ ISSN (Online): 2319-7064}

Index Copernicus Value (2013): 6.14 | Impact Factor (2014): 5.611

materials. Lead is a well known toxicant that has several deleterious effects even at minute concentration and has no known function in biochemical processes [13]. An onset of lead pollution of surface water has been reported $[14 ; 15]$. The source being the use of lead gasoline [16]. Lead is commonly known to inhibit active transport mechanism involving ATP to depress the activity of the enzyme cholinesterase, to suppress cellular oxidation-reduction reaction and to inhibit protein synthesis [17]. Prolonged consumption of Lead may also increase red cell fragility and kidney tubular cells and may become necrotic, while chronic exposure may lead to intestinal nephrites. Prolong consumption of Lead may result to impairment of the hearing process (18).

The average concentration of $\mathrm{Mn}$ in the local beverage drinks were below the WHO permissible limits of $0.4 \mathrm{mgL}^{-1}$

. Mn is an essential element and one of moderate toxicities. Mn has been implicated in neurological problems, especially when inhaled [7].

The average concentration of $\mathrm{Fe}$ in the present study is above the WHO recommended limit of $0.3 \mathrm{mgL}^{-1}$ in Burukutu and Kunu drinks. The high metal content of Fe in Burukutu and Kunu could be from cooking utensil where high temperature was applied during the production process. This is not acceptable to the comsumers, as it could give rise to iron dependent bacteria which in turn cause further deterioration in the quality of local drinks by prohibition of slimes, or objectionable colour[19]. The results obtained may be due to run-offs and geological formations of the water samples and metal instrument used in the preparation processes while in Zobo drinks, the mean concentration of metal was below the WHO permissible limit of $0.3 \mathrm{mgL}^{-1}$ for beverage drinks. The mean concentration of $\mathrm{Zn}$ was found to be below the WHO limit for local drinks standard of 3.0 $\mathrm{mgL}^{-1}$ in all the three popular local drinks in this study. Copper was not detected in Burukutu and Kunu but the mean concentration of $\mathrm{Cu}$ in Zobo was below or fall within WHO recommended range of $2.0 \mathrm{mgL}^{-1}$ for local beverage drinks without adverse effect.

\section{Conclusion}

The study has presented metal concentration $(\mathrm{Cu}, \mathrm{Zn}, \mathrm{Fe}$, $\mathrm{Mn}, \mathrm{Pb}, \mathrm{Cr}, \mathrm{Ni}, \mathrm{Ca}, \mathrm{Mg}, \mathrm{Na}$ and $\mathrm{K}$ ) in Burukutu, Kunu and Zobo drink popularly consumed in Benue State, Nigeria. The average concentrations level of $\mathrm{Pb}$ in the drink samples were above the WHO recommended guideline values for beverages drnks. Iron content was also found to be higher than WHO recommended guideline values for beverages drinks. The reason for higher lead levels is as a result of the source of water and iron levels in Burukutu and Kunu drinks are attributed to the use of rusting metal drums and vessels in processing of the two drinks, unlike Zobo drink which does not require the same processing method. Therefore, consumers should be careful of the environments where these drinks are prepared as well as the vessels used.

\section{References}

[1] Iwegbue, C.M.A. Composition and daily intake of some trace metals from canned beer in Nigeria J.inst Brew; 116: 312-315.2010.

[2] Budinoval , T.K; Gergora, K.M; Metrov, H.V and Minka , V.N. Removal of metal ions from aqueous solution by activated carbon obtained from different raw material, J. of chem. Tech. and Biotech, Co. 179-180. 1994.

[3] Alex, A. nigeriascienceslories.blogspot.com 2010.

[4] Oluwataniwa, A. heathycase.blogspot.com 2014.

[5] Underwood, E.J. Trace element toxicant occurring in foods, National Academy of Science ,Washington, pp:43-47 1973

[6] Ajaero, C. A Brand New Image For Benue,Newswatch magazine(Newswatch Communications). Retrieved 2007

[7] Aremu,M.O; Atolaiye ,B.O; Gav, B.L; Opaluwa,O.D; Sangari,D.U and Madu,P.C. metal concentrations in sediments and water from Rivers Doma, Farinruwa and Mada in Nasarawa State, Nigeria, Journal of Environmental Chemistry and Ecotoxicology, vol.3(9), pp.242-249, 2011

[8] Aremu, M.O; Olanisakin, Ahmed, S.A. Assessment of heavy metal content in some selected agricultural products planted along some roads in Nasarawa State, Nigeria, Journal of Engineering and Applied sciences, 1(3):197-204. 2006.

[9] Fleck,H. Introduction to Nutrition $3^{\text {rd }}$ Edition. Macmillan publishing Co. Inc. New York, pp.207-219, 1976.

[10] Shills,M.E.G and young, V.R. Modern Nutrition in health and disease. Lea and Febiger, Philadephia, USA. In:Nurtrition Edition. Nieman,C.N. WmCbrown Publishers. Dubuque, USA.pp:276-282, 1988.

[11] Ademoroti, C.M.A. Environmental Chemistry and Toxicology. Foludex press Ltd ; Ibadan, Nigeria, pp.2030. 1996.

[12]Lenntech. http:// www.lenntech.com/heavy-metals.htm 2008.

[13] Crossby, N.T. Determination of metals in food. A review. Analyst, 102:225-268. 1997.

[14] Mombershora, C.O; Osibanjo,O. and Ajayi ,S.O. Pollution studies on Nigeria Rivers; the onset of Lead pollution of surface waters in Ibadan. Environment. International,9: 81-84.1983.

[15] Okoye, B.C.O. Heavy metal and organisms in the Lagos Lagoons, International journal of Environmental studies, 37: 285-292. 1991.

[16] Osibanjo, O and Ajayi, S.O. Trace metal levels in the trace barks as an indication of pollution . Environment, International,4: 236-244. 1980.

[17] Waldren, H.A and Stofen, D. Sub-clinical Lead poisoning, Academic press, New York, pp84. 1974.

[18]Fell,G.S . Lead toxicity problems of definition and laboratory evaluation. Annual Clinical Biochemistry, 21:453-460. 1984.

[19] Okedi, C and Oni, O.O. Basic water Treatment Operation. Edited by outreach department, Published by National Water Resources Institute, Kaduna, pp: 1-90. 1997. 


\section{International Journal of Science and Research (IJSR) \\ ISSN (Online): 2319-7064 \\ Index Copernicus Value (2013): 6.14 | Impact Factor (2014): 5.611}

Table 1: Metal concentrations $\left(\mathrm{mgL}^{-1}\right)$ in Burukutu Drink Samples from Benue State ,Nigeria.

\begin{tabular}{|l|l|l|l|l|l|l|l|l|}
\hline $\mathrm{Metal}$ & MKB & GBB & OTB & OJB & KAB & Mean & SD & $\mathrm{CV}^{\%}$ \\
\hline $\mathrm{Cu}$ & BDL & BDL & BDL & BDL & BDL & NA & NA & NA \\
\hline $\mathrm{Zn}$ & 0.46 & 0.53 & 0.62 & 0.63 & 0.66 & 0.58 & 0.08 & 13.10 \\
\hline $\mathrm{Fe}$ & 0.43 & 1.70 & 1.06 & 3.12 & 0.71 & 1.40 & 0.96 & 68.50 \\
\hline $\mathrm{Mn}$ & 0.04 & 0.06 & 0.05 & 0.07 & 0.07 & 0.06 & 0.01 & 23.30 \\
\hline $\mathrm{Pb}$ & BDL & BDL & BDL & 0.13 & BDL & 0.03 & 0.05 & 170 \\
\hline $\mathrm{Cr}$ & BDL & BDL & BDL & BDL & 0.08 & 0.02 & 0.03 & 170 \\
\hline $\mathrm{Ni}$ & BDL & BDL & 0.03 & BDL & BDL & 0.01 & 0.01 & 110 \\
\hline $\mathrm{Ca}$ & 37.27 & 21.71 & 19.43 & 26.45 & 21.53 & 25.28 & 6.43 & 25.44 \\
\hline $\mathrm{Mg}$ & 5.42 & 5.47 & 4.11 & 4.51 & 5.21 & 4.95 & 0.54 & 10.91 \\
\hline $\mathrm{Na}$ & 4.10 & 5.40 & 3.50 & 5.20 & 4.10 & 4.46 & 0.72 & 16.14 \\
\hline $\mathrm{K}$ & 3.90 & 4.20 & 5.20 & 5.20 & 7.80 & 5.26 & 1.37 & 26.05 \\
\hline
\end{tabular}

$\mathrm{MKB}=$ Makurdi Burukutu;GBB= Gboko Burukutu; OTB= Otukpo Burukutu;OJB= Oju Burukutu; KAK= Katsina $-\mathrm{Ala}$ Burukutu; $\mathrm{BDL}=$ Below Detection Level; $\mathrm{NA}=$ Not Applicable; $\mathrm{SD}=$ Standard Deviation; $\mathrm{CV} \%$ Coefficient of Variation Percent

Table 2: Metal Concentrations $\left(\mathrm{mgL}^{-1}\right)$ in Kunu Drink Samples from Benue State, Nigeria.

\begin{tabular}{|l|l|l|l|l|l|l|l|l|}
\hline Metal & MKK & GBK & OTK & OJK & KAK & Mean & SD & $\mathrm{CV}^{\circ} \%$ \\
\hline $\mathrm{Cu}$ & BDL & BDL & BDL & BDL & BDL & NA & NA & NA \\
\hline $\mathrm{Zn}$ & 0.53 & 0.45 & 0.68 & 0.55 & 0.57 & 0.56 & 0.08 & 13.57 \\
\hline $\mathrm{Fe}$ & 0.78 & 3.05 & 0.43 & 0.35 & 0.28 & 0.98 & 1.05 & 107.14 \\
\hline $\mathrm{Mn}$ & 0.05 & 0.06 & 0.02 & 0.06 & 0.07 & 0.05 & 0.02 & 32.00 \\
\hline $\mathrm{Pb}$ & 0.13 & BDL & 0.13 & 0.13 & $\mathrm{ND}$ & 0.08 & 0.06 & 77.50 \\
\hline $\mathrm{Cr}$ & BDL & BDL & BDL & BDL & 0.08 & 0.02 & 0.03 & 170 \\
\hline $\mathrm{Ni}$ & BDL & 0.03 & BDL & BDL & BDL & 0.01 & 0.01 & 110 \\
\hline $\mathrm{Ca}$ & 34.29 & 35.12 & 27.06 & 36.57 & 36.52 & 34.01 & 3.34 & 9.82 \\
\hline $\mathrm{Mg}$ & 4.11 & 4.00 & 5.47 & 4.11 & 5.36 & 4.77 & 0.59 & 12.37 \\
\hline $\mathrm{Na}$ & 3.70 & 3.20 & 5.10 & 3.40 & 3.20 & 3.66 & 0.75 & 20.49 \\
\hline $\mathrm{K}$ & 4.30 & 7.80 & 6.10 & 7.80 & 8.10 & 6.82 & 1.44 & 21.11 \\
\hline
\end{tabular}

MKK=Makurdi Kunu; GBK= Gboko Kunu ;OTK= Otukpo Kunu;OJK= Oju Kunu;KAK= Katsina - Ala Kunu;

$\mathrm{BDL}=$ Below Detection Level ; $\mathrm{NA}=$ Not Applicable; $\mathrm{SD}=$ Standard Deviation; $\mathrm{CV} \%=$ Coefficient of Variation Percent

Table 3: Metal concentrations $\left(\mathrm{mgL}^{-1}\right)$ in Zobo Drink Samples from Benue State, Nigeria.

\begin{tabular}{|l|l|l|l|l|l|l|l|l|}
\hline Metal & MKZ & GBZ & OTZ & OJZ & KAZ & Mean & SD & CV $^{\%}$ \\
\hline $\mathrm{Cu}$ & 0.03 & BDL & BDL & BDL & BDL & 0.01 & 0.01 & 110 \\
\hline $\mathrm{Zn}$ & 0.62 & 0.45 & 0.45 & 0.33 & 0.46 & 0.47 & 0.09 & 20 \\
\hline $\mathrm{Fe}$ & 0.28 & 0.07 & 0.07 & 0.28 & 0.21 & 0.18 & 0.18 & 52.78 \\
\hline $\mathrm{Mn}$ & $\mathrm{ND}$ & 0.13 & 0.06 & 0.14 & 0.47 & 0.16 & 0.16 & 101.25 \\
\hline $\mathrm{Pb}$ & $\mathrm{BDL}$ & 0.13 & BDL & BDL & BDL & 0.03 & 0.05 & 170 \\
\hline $\mathrm{Cr}$ & 0.17 & 0.08 & BDL & BDL & BDL & 0.05 & 0.07 & 136 \\
\hline $\mathrm{Ni}$ & BDL & BDL & BDL & 0.03 & 0.03 & 0.01 & 0.01 & 120 \\
\hline $\mathrm{Ca}$ & 29.25 & 39.15 & 35.30 & 39.50 & 40.00 & 36.64 & 4.05 & 11.05 \\
\hline $\mathrm{Mg}$ & 4.36 & 5.11 & 4.61 & 5.42 & 4.80 & 4.86 & 0.37 & 7.61 \\
\hline $\mathrm{Na}$ & 4.50 & 4.30 & 4.20 & 5.90 & 4.80 & 4.74 & 0.62 & 13.10 \\
\hline $\mathrm{K}$ & 5.90 & 7.20 & 7.80 & 3.90 & 13.50 & 7.66 & 3.21 & 41.91 \\
\hline
\end{tabular}

MKZ=Makurdi Zobo; GBZ= Gboko Zobo;OTZ= Otukpo Zobo;OJZ= Oju Zobo;KAZ= Katsina - Ala Zobo ;

$\mathrm{BDL}=$ Below Detection Level ; $\mathrm{NA}=$ Not Applicable; $\mathrm{SD}=$ Standard Deviation; $\mathrm{CV} \%=$ Coefficient of Variation Percent

Table 4: Levels of metals concentration $\left(\mathrm{mgL}^{-1}\right)$ in Burukutu, Kunu and Zobo compared with WHO Standard.

\begin{tabular}{|l|l|l|l|l|}
\hline Mineral & Burukutu & Kunu & Zobo & WHO value,2011 \\
\hline $\mathrm{Cu}$ & NA & NA & 0.01 & 2.0 \\
\hline $\mathrm{Zn}$ & 0.88 & 0.56 & 0.47 & 3.0 \\
\hline $\mathrm{Fe}$ & 1.40 & 0.98 & 0.18 & 0.3 \\
\hline $\mathrm{Mn}$ & 0.06 & 0.05 & 0.16 & 0.4 \\
\hline $\mathrm{Pb}$ & 0.03 & 0.08 & 0.03 & 0.01 \\
\hline $\mathrm{Cr}$ & 0.02 & 0.02 & 0.05 & 0.05 \\
\hline $\mathrm{Ni}$ & 0.01 & 0.01 & 0.01 & 0.02 \\
\hline $\mathrm{Ca}$ & 25.28 & 34.01 & 36.64 & 75 \\
\hline $\mathrm{Mg}$ & 4.95 & 4.77 & 4.86 & 50 \\
\hline $\mathrm{Na}$ & 4.46 & 3.66 & 4.74 & 200 \\
\hline $\mathrm{K}$ & 5.26 & 6.82 & 7.66 & 65 \\
\hline
\end{tabular}

NA= Not Applicable; WHO- World Health Organization 